\title{
ENVIRONMENTAL DEGRADATION AND POVERTY NEXUS: Evidence From Coral Reef Destruction In Indonesia
}

\author{
Kanetasya Sabilla \\ School of Environment and Development \\ The University of Manchester, United Kingdom \\ Email:kanetasya@gmail.com
}

\begin{abstract}
In a rural area, environmental degradation and poverty nexus focuses on the high-dependency of poor people to natural resources-based livelihood. Arguably, limited assets of poor people cause them to be unable to cope with natural resources degradation and to undertake sustainable practice in their livelihood activities. This study attempts to find the nexus between environmental degradation and poverty in the case of coral reef destruction in Indonesia by applying secondary research as a methodology. A sustainable livelihood framework is applied to analyze small-scale fisher people's vulnerability and capacity to destruct. This study finds that small-scale fisher-people have limited assets to cope with coral reef destruction; however, the same condition leads them to destruct coral reef by doing the destructive fishing practice. This condition causes them to be trapped in the downward spiral of environmental degradation and poverty. Moreover, small-scale fisher-people can overcome this problem by developing self-governance common pool resources to conserve coral reef and increase their livelihood sustainability.
\end{abstract}

Keywords: environmental degradation, poverty nexus, coral reef destruction, small-scale fisher-people, Indonesia, sustainable livelihood framework

\begin{abstract}
Abstrak
Di daerah pedesaan, degradasi lingkungan dan nexus kemiskinan berfokus pada ketergantungan masyarakat miskin yang tinggi terhadap mata pencaharian berbasis sumber daya alam. Dapat diperdebatkan, aset terbatas orang miskin menyebabkan mereka tidak mampu mengatasi degradasi sumber daya alam dan melakukan praktik berkelanjutan dalam kegiatan mata pencaharian mereka. Studi ini mencoba untuk menemukan hubungan antara degradasi lingkungan dan kemiskinan dalam kasus perusakan terumbu karang di Indonesia dengan menerapkan penelitian sekunder sebagai metodologi. Kerangka kerja mata pencaharian berkelanjutan diterapkan untuk menganalisis kerentanan dan kapasitas nelayan skala kecil untuk dirusak. Studi ini menemukan bahwa para nelayan skala kecil memiliki aset terbatas untuk mengatasi kerusakan terumbu karang, namun kondisi yang sama menyebabkan mereka merusak terumbu karang dengan melakukan praktik penangkapan ikan yang merusak. Kondisi ini menyebabkan mereka terjebak dalam spiral penurunan kualitas lingkungan dan kemiskinan. Selain itu, nelayan skala kecil dapat mengatasi masalah ini dengan mengembangkan tata kelola sumber daya bersama untuk melestarikan terumbu karang dan meningkatkan keberlanjutan mata pencaharian mereka.
\end{abstract}

Kata kunci: degradasi lingkungan, nexus kemiskinan, penghancuran terumbu karang, nelayan skala kecil, Indonesia, kerangka mata pencaharian berkelanjutan 


\section{INTRODUCTION}

Environmental degradation or the destruction of natural resources, such as water, land, air, forests, and biodiversity, can be attributed to several factors. Besides the 'natural' disaster, the human fault is the key factor that affects environmental degradation due to unsustainable consumption and production. Further to this argument, some theorists argue over who contributes the most to environmental degradation.

Some theorists believe that poor people have contributed the most to environmental degradation. The World Commission on Environment and Development (1987) or Brundtland Report also blamed the poor for causing worldwide environmental problems. Moreover, UNEP (2000) reported that poverty and population growth leads to environmental degradation in most developing countries. World Bank (2007) argued that in order to consume for the present and future period, poor people might degrade the environment.

Poor people still depend on the natural resources for their main source of income, particularly in rural areas (World Bank, 2002; Millennium Ecosystem Assessment, 2005; WRI, 2005). According to the World Bank (2002) data, 90 percent of people living in extreme poverty depend on forest resources. FAO (2005) also stated that there are about 78 million smallscale fisher-people in the world who depend on the fish catch activities directly. At the country level, for instance, the income of 40 percent of the poorest households in Zimbabwe relies on natural resources.

Arguably, poverty causes them to utilize the natural resources unsustainably (World Commission on Environment and Development, 1987). They do not have sufficient assets to avoid environmental degradation since they have struggled to fulfill their basic needs in daily life (McGregor, Barker, \& Evans, 1998). Therefore, they do the dangerous practice of their livelihoods, such as burning the forest to open new farmland, bombing the sea to catch fish, using chemical fertilizers that can pollute the water and others that degrade the environment.

The conflict of using common natural resources may also lead the poor to degrade the environment. The theory of the tragedy of the commons (Hardin, I968) argued that people are rational; thus, they want to maximize the profit without considering the effects on the shared natural resources that they use. However, this theory was rejected by Ostrom (I990), who believes users have their own institutions to govern the commons.

Conversely, the poor also become a group of people who suffer the most from environmental degradation. UNDP (I998: 66) believes that "environmental damage almost always hits those living in poverty the hardest." Poor people are vulnerable to environmental degradation because they do not have sufficient investment to overcome the environmental change and the lack of environmental entitlements (Angelsen, I995). Moreover, the World Bank (2007a) mentioned that poor people highly depend on natural resources as the asset that they can access easily.

Therefore, environmental degradation and poverty nexus is a reciprocal cause and effect concept. Jehan \& Umana (2003) conclude that the environment can affect poverty in three ways: livelihoods, health, and vulnerability. In another way, poverty can ruin the environment as well by forcing the poor to destruct the environment by boosting economic growth at the expense of the environment, and by influencing people to lower their environmental concern.

In developing countries, environmental degradation and poverty nexus have been related to the vicious circle of poverty, where poor people are compelled to exploit the natural resources as their survival strategy. However, the exploitation results in further degradation of the environment, which in the end can cause further difficulties and uncertainties to survive (World Commission on Environment and Development, 1987). Some authors even believe that environmental degradation and 
poverty nexus are more than just a vicious circle; instead, they form a downward spiral that means the future condition of both environment and poverty is worse than in the previous period (Jehan \& Umana, 2003).

In relation to the marine fishery issue, it is interesting to find the environmental degradation and poverty nexus in the coral reefs destruction problem since coral reefs can contribute to approximately 25 percent of all marine life (Cesar, Burke, \& Pet-Soede, 2003). Currently, the destruction of coral reefs is in serious condition. According to the same report, 27 percent of coral reefs in the world have destroyed and 60 percent of them will be lost in the 30 years if there is no further preventive action, whereas about 40 percent of the world's population lives less than roo kilometers from the sea and rely on fish stocks as their livelihood. The loss of coral reef will reduce the number of fish stocks in the sea significantly, thereby affecting the income of fisher-people negatively and contributing to the increased poverty rate (Cesar et al., 2003).

Moreover, human activities are the most influential factor that causes coral reef destruction (Freed \& Granek, 20I4). Human activities such as tourism overuse, destructive fishing practices, and runoff and land-based pollution created stress in the coral reef area resulting in coral reef destruction (Cesar et al., 2003). Conversely, poor fisher-people are vulnerable to environmental degradation, such as coral reef destruction. It is estimated that coral reef destruction will reduce fisher people's fish catch, and the costs that have to be burdened by them are higher than the benefits (Cesar et al., 2003).

One of the countries with a large proportion of coral reef destruction is Indonesia. In this country, the number of coral reef destruction increased from around Io percent in the I950s to be 50 percent in the $2000 \mathrm{~s}$ (Burke, Selig, \& Spalding, 2002). The importance of coral reef in Indonesia also comes from their support to marine fisheries, which have become the main livelihood of 864 thousand households or I.33 percent of Indonesia total households in 2015 (BPS, 2015). Furthermore, as the country with the largest economy in South East Asia, Indonesia is still struggling to do the poverty eradication agenda. Rural poverty is still dominated by the number of poor people in Indonesia. There is I4.I percent of poor people living in a rural area (BPS, 20I6).

The aim of this study is to understand the relationship between coral reef destruction and poverty in Indonesia. From the previous study of environmental degradation and poverty nexus, this study will also try to link the gap in the institutional aspect of the issue; specifically, the informal rules among the users of natural resources which back up the theory of the governance of common-pool resources from Ostrom (I990). Moreover, the lack of research about the poverty and fishery sector (Bene, 2003) or coral reef-dependent livelihood (Cinner, 20I4) has become the consideration to conduct this study.

\section{LITERATURE REVIEW}

\section{Environmental Degradation and Poverty Nexus}

Poverty can cause environmental degradation due to several factors. First, the Neo-Malthusian theory believes the population growth can threaten the environment since there will be a higher rate of consumption than production (Gould, 2009). Therefore, in the long term, there will be a lower level of resources per capita. Second, poverty may cause them to be less able to maintain the sustainability of resource use (World Commission on Environment and Development, 1987) since poor people have a lack of assets even to survive in their daily life (McGregor et al., I998). Third, poor people also more likely to overuse natural resources because they think there will be high discount rates in the future that will lower their value of income. To overcome this problem, they gather their yields in a short time as much as they can. Their willingness to maximize the profit from yields selling can affect them to overuse natural resources.

In contrast, the dependencies of the poor on natural resources have transformed 
them into the vulnerable group to face the environmental degradation (World Commission on Environment and Development 1987, UNDP I998, World Bank 2007a). As the utility of natural resources reduces or even losses due to degradation, poor people are no longer able to utilize natural resources. They may lose their main productive assets because of natural resources degradation (Nadkarni, 200o). Consequently, their production decreases, which, ultimately, can reduce the poor's income since they most likely do not have an alternative livelihood. Their vulnerability mainly comes from the limited assets that they have (Angelsen, I997). The term poverty itself is associated with "the range of lack of the various assets" (Reardon \& Vosti, I995: I495). Furthermore, poor people have limited choices regarding their livelihood; hence, they do not have the chance to extend their income possibility (Reardon \& Vosti, I995). Since they possibly only rely on natural resources, mainly in rural areas, they have less ability to overcome environmental degradation.

The nexus between environmental degradation and poverty has been described as a vicious circle. It means that poor people affect environmental degradation, which makes them suffer the most, and their condition leads them to exploit the environment. Moreover, some theorists even argue that environmental degradation and poverty nexus is more than just a vicious circle but a downward spiral (World Commission on Environment and Development, I987; Jehan \& Umana, 2003); in other words, previous environmental degradation will worsen poor people's current condition. Chambers (I988) argues that poor people are marginalized from the technological development for natural resource utilization, which is usually owned by rich people. As they cannot afford the ownership for the excellent quality of lands, they probably choose to migrate. Unfortunately, they could settle only in the vulnerable area and could not adopt sustain practice to utilize their livelihood due to their uncertain tenure, lack of advanced technology, and poverty. Therefore, poor people can be trapped in the cumulative vulnerability that leads them cannot move out from the downward spiral of poverty and environmental degradation.

In proving the environmental degradation and poverty theory, there was some researches that attempt to identify the link between poverty and environmental degradation. First, the important research from Duraiappah (I998) reviews some existing literature to find the link between environmental degradation in the forest sector, land degradation, water, and air to exogenous poverty; power, wealth, and greed; institutional failure; market failure; and endogenous poverty. Consequently, the poor cannot be blamed for mainly causing environmental degradation because of the other groups' interests, as well as institutional and market failures, contribute more to the situation. Second, Ravnborg (2003), who conducted her research in Nicaraguan Hillsides, Central America, found that poor people were not the main cause of environmental degradation. Finally, Khan \& Khan (20II) found that the problem of poor fisher-people came from the failure to access the credit market, which 'forces' them to use destructive fishing methods.

\section{Sustainable Rural Livelihoods Framework}

In order to find the link between environmental degradation and poverty, this research adopts the sustainable livelihood framework. Since the analysis of environmental degradation and poverty nexus is closely related to the poor's livelihood in the rural area, it is necessary to apply a framework that can describe the means to sustain the livelihood strategy of the poor (Scoones, 1998). The term livelihood involves people's capabilities and means of living (Chambers \& Conway, I99I). The sustainable livelihood approach is also related to the vulnerability context.

Figure I. Sustainable Livelihoods Framework 


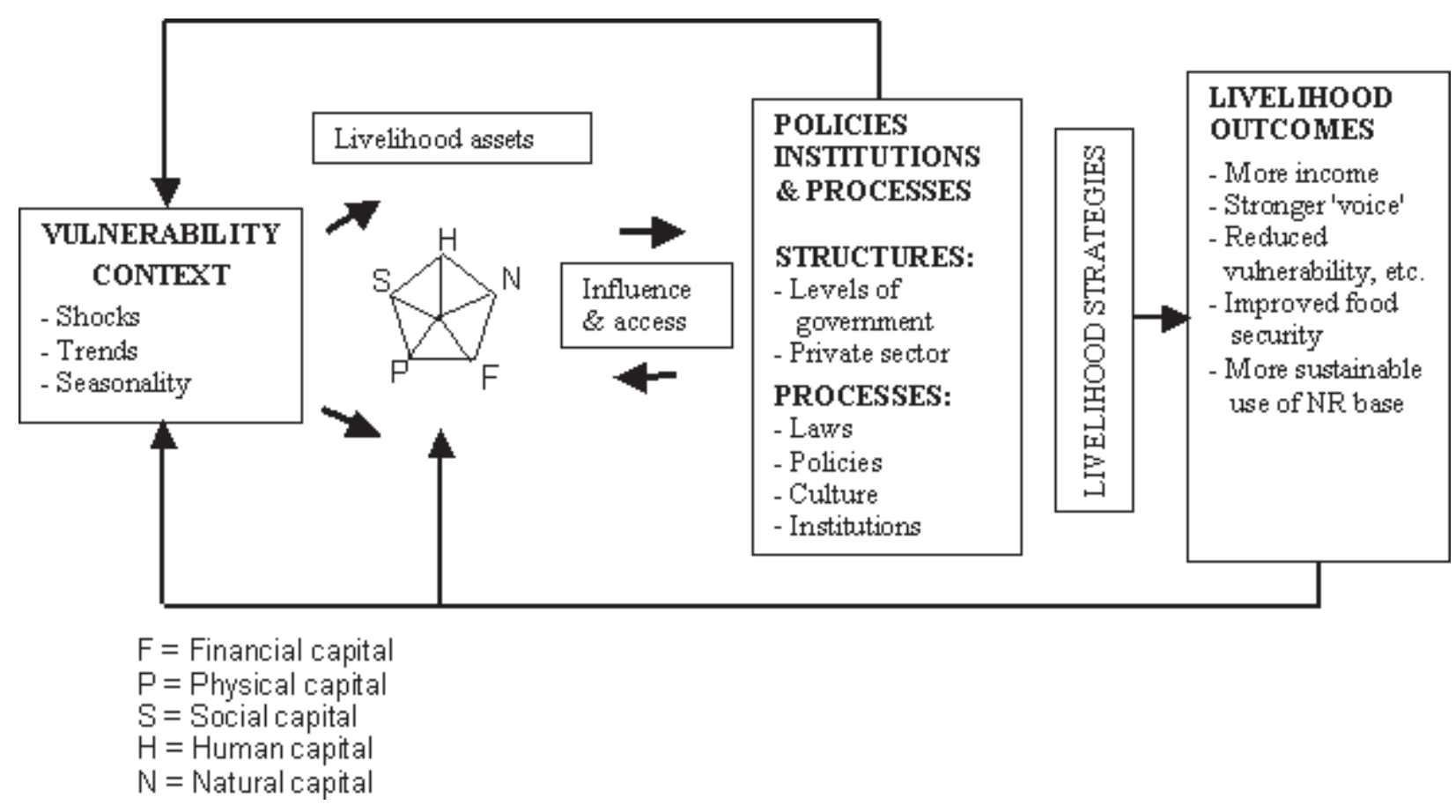

Source: Baumann (2002: 10)

The Framework Components

\section{Vulnerability context}

The people's livelihood should be resilient to shocks, trends, and seasonality. The changing condition that occurs fast can affect the vulnerability of livelihoods (Chambers \& Conway, I99I). Vulnerable in this context means that the poor people are not able to recover after the shocks, trends, or seasonal shifts that have afflicted them.

\section{Assets}

The sustainable livelihood framework consists of the list of assets owned by the poor household (Ellis 2000). The following are the five categories of assets' definition, according to Scoones (I998) and Ellis (2000):

- Natural capital is related to the "natural resource stocks' such as soil, water, and air, and 'environmental services,' such as hydrological cycle and pollution sinks that useful for livelihoods (Scoones, I998).

- Human capital is the quality of labor, such as skills, knowledge, education, health, and others (Scoones, I998).
- Financial capital is the economic assets, such as cash, credit/debit, savings, and other financial assets that are critical to achieving livelihood strategy (Scoones, I998).

- Social capital is "the social resources ... which people draw when pursuing ... livelihood strategies requiring coordinated actions" (Scoones, I998: 8).

- Physical capital means the "capital that is created by economic production processes." This category of capital is added by Ellis (2000:32).

The sustainable livelihood framework can address poor people's vulnerability (DFID, I999; Allison \& Ellis, 200I). The vulnerability of the poor is related to their ability to access the assets (Baumann, 2002) because the assets provide the "capability to be and to act" for the poor (Bebbington, I999: 2022). Poor people are not able to access the essential assets for their life. For example, some theorists argue that poor people have limited access to productive resources (Baumann, 2002; Ravnborg, 2003), credit market (Khan \& Khan, 20II), and education (Parekh, Killoran, \& Crawford, 20II). 


\section{Institutions}

Institutions are one of the types of structures and processes that form livelihoods, besides organizations, policies, and legislation (DFID, I999). Like the shocks, trends, and seasonality, institutions can have a direct effect on poor people, mainly to determine their access to the assets. The institution can also limit people's opportunities to livelihood strategies.

\section{The Institutional Arrangement for Common Pool Resources}

Commonly Natural resources are often used because there is no explicit institutional arrangement by which they are ruled. This situation can cause people to use natural resources carelessly and unsustainable because they will gain more profit if they can utilize natural resources for themselves. Therefore, the unsuitable institutional arrangement for common resources is argued as one of the causes of environmental degradation (Hardin, I968).

\section{The Tragedy of the Commons}

The tragedy of the commons is the term used to define the problem with the open-access of natural resources, as developed by Hardin (ig68). An illustration of pasture without any regulation of ownership is the example used by Hardin (I968) to explain this theory. Since there are many herders on the pasture that bring their own animals, and each herder tries to maximize his profit, they want to graze more animals to the limited space of pasture. On the other hand, there is no limitation to the number of animals on the pasture. As a result, the pasture can degrade due to overgrazing by the herders. The pasture degradation can cause the loss for the herders as well, resulting from the degraded pasture cannot be utilized by the animals maximally. From this perspective, the open-access of natural resources can be detrimental to both the environment and the users. Therefore, there should be an institution to rule the ownership of the common pool resources which can be done by the government or private sector intervention (Hardin, I968)

\section{Self-Governance of Common Pool Resources}

The argument to govern the common by government or private party has been debated by some theorists. Ostrom (I990) believed that private property was not the only way to govern the common pool resources because the users actually can communicate with each other with local communities' informal cooperation. In her book, Ostrom (I990) argues that collective action became the mean to prevent natural resources degradation rather than establish a formal institutional arrangement by the government or private sector as what Hardin (I968) has suggested. Ostrom (2010) further argues that the effectiveness to govern the complex natural resources used commonly was determined significantly by the stakeholders' relationship, rather than depending solely on private or government ownership. Ostrom (I990) provided evidence of the self-governance common pool resources in some countries. One of the examples was taken from the irrigation community system in the Philippines called zanjera.

\section{METHODOLOGY}

In order to answer the research aim, this study was a desk-based study. The study used secondary research data by collating and analyzing the previous studies based on published journal papers or news about the related topic. This type of research is more efficient in terms of time and cost than conducting primary data (Lefever, Dal, \& Matthiasdottir, 2007). Moreover, secondary research is useful to avoid subjectivity that may arise in collecting data from the fieldwork because the research can be conducted to analyze more than one case study in the same area. These advantages are suitable to answer the research questions that emphasized understanding the nexus between environmental degradation and poverty by analyzing coral reef destruction in Indonesia as the case study.

\section{RESULTS AND DISCUSSION}

\section{I. Sustainable Livelihood Analysis}


This section will assess the five categories of capital owned by the poor fisher-people who live in the Jakarta Bay and Spermonde Islands. The assessment of poor people's physical, financial, human, social, and natural capital will explain how the coral reef destruction can affect their livelihood. Furthermore, analysis is required to demonstrate the cumulative vulnerability experienced by the small-scale fisher-people as evidence that poor people are trapped in a downward spiral due to environmental degradation. The figure below explained the theoretical framework for this study:

Figure 2. Sustainable Rural Livelihood Framework for This Study

Source: adapted from Scoones (1998), Ellis (2000)

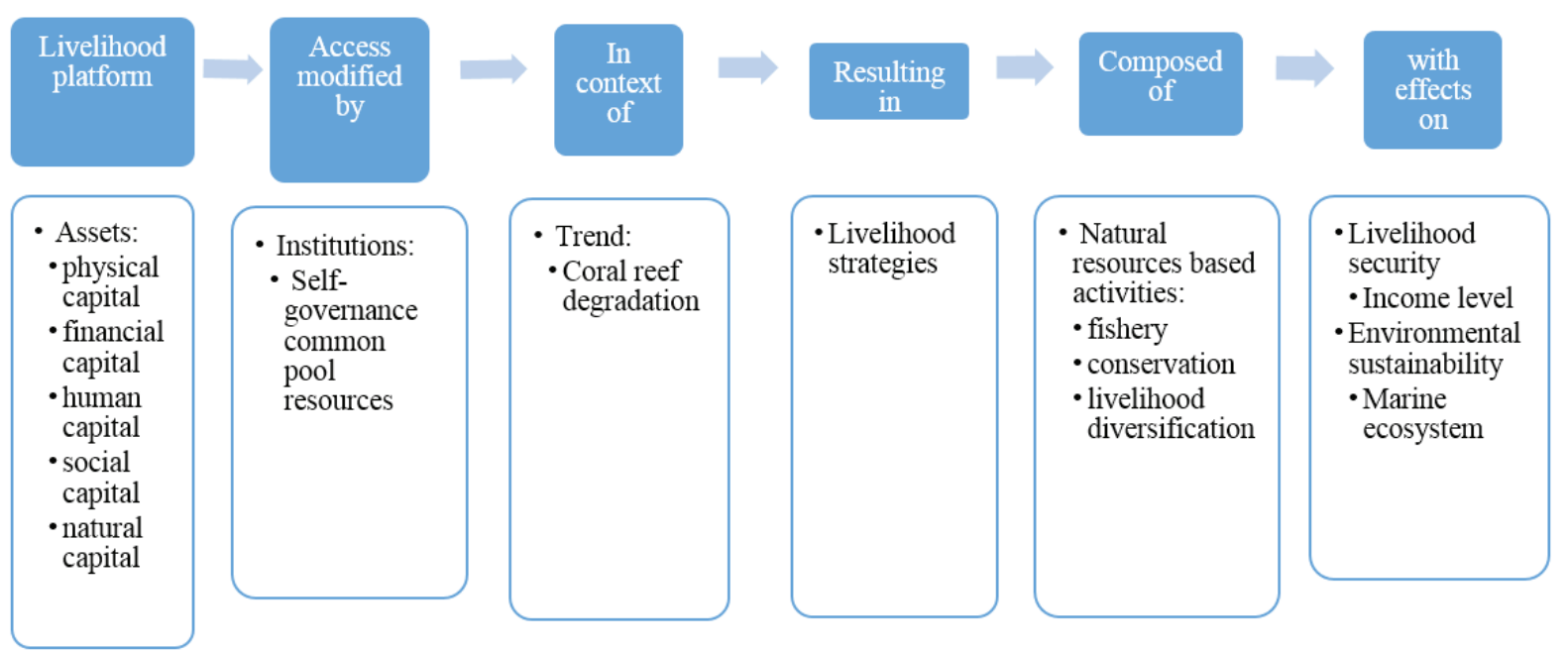

Assets: Findings and Analysis

Table I. Findings on Assets Categories

\begin{tabular}{lll}
\hline Assets Categories & $\begin{array}{l}\text { Jakarta Bay (Baum, Kusumanti, \& Breckwoldt. } \\
\text { 2016) }\end{array}$ & $\begin{array}{l}\text { Spermonde Islands (Ferse, Knittweis, Krause, } \\
\text { Maddusila, \& Glaser, 2012) }\end{array}$ \\
\hline Physical capital & $\begin{array}{l}\text { Only } 10 \text { percent of households in the Jakarta } \\
\text { Bay who own the boat, while the remaining } 90 \\
\text { percent of households do not own a boat and } \\
\text { work as labors for other fisher-people }\end{array}$ & $\begin{array}{l}\text { There was only respectively } 43 \text { and } 21 \text { percent of } \\
\text { fisher-people in Barrang Lompo and Karanrang } \\
\text { Island, which own boat. They usually rent the } \\
\text { The small-scale fisher-people used Muro-ami } \\
\text { (drive-in net) gear to gain more fish catch every } \\
\text { time they went fishing. They also used blast } \\
\text { and cyanide fishing gear. }\end{array}$ \\
\hline
\end{tabular}




\begin{tabular}{|c|c|}
\hline Assets Categories & $\begin{array}{l}\text { Jakarta Bay (Baum, Kusumanti, \& Breckwoldt. } \\
\text { 2016) }\end{array}$ \\
\hline Financial capital & $\begin{array}{l}\text { One fisherman in the Kamal Muara admitted } \\
\text { that, on average, every day, he could earn in- } \\
\text { come up to IDR } 70,000 \text { (around GBP 4.0), while } \\
\text { in the dry season, he had to work harder to } \\
\text { earn income from fishing or at least provided a } \\
\text { fish caught for eating. However, the attempt to } \\
\text { work harder might harm their financial capital } \\
\text { since they should buy more amount of fuel for } \\
\text { fishing. Consequently, there is } 62.9 \text { percent of } \\
\text { people living under IDR 1,000,000 (around GBP } \\
\text { 58.0) of total income per month. }\end{array}$ \\
\hline
\end{tabular}

Human capital

74.3 percent of people had enrolled in high capacity building for poor people can influence their livelihoods. Moreover, 42.1 percent or not more than half of the people in the mainland had been trained in fishing techniques. However, they are still at risk of adapting to environmental change because most of them receive only training in fishing techniques. school. Besides formal education, training, and

\section{Spermonde Islands (Ferse, Knittweis, Krause,} Maddusila, \& Glaser, 2012)

The usual monthly income of small-scale fisherpeople in Barrang Lompo and Karanrang Islands respectively was IDR $613,768-875,000$ (around GBP $35.0-50.0$ ) and IDR 786,208-844,684 (around GBP 45.0 - 48.0). However, they will obtain a lower amount of income in the bad season. Their access to the middlemen will be the most important coping strategy to overcome this problem. From the middlemen, they can borrow some amount of money. There were 95 and 97 percent of smallscale fisher-people in respectively Barrang Lompo and Karanrang Islands, which had access to credit from their middlemen.

The small-scale fisher-people in the Spermonde Islands did not complete their educational level as high as those in the Jakarta Bay. No one in the Barrang Lompo Island had graduated senior high school, and only 4 percent of people in the Karanrang received a high school education (Ferse et al. 2012). The majority of the small-scale fisher-people in the Barrang Lompo and Karanrang Islands could only finish elementary school. No one in the Barrang Lompo Island who participated in NGO training, there were at least 17 percent of small-scale fisher-people participated in NGO training in Karanrang Island.

\begin{tabular}{ll}
\hline Social capital & Small-scale fisher-people have social capital in \\
the form of the membership and networking \\
in trade among the small-scale fisher-people \\
to support their livelihood. They often shared \\
daily needs, such as vegetables and fish, and \\
help each other. Such generosity is informal but \\
vital in a community.
\end{tabular}

Small-scale fisher-people in Spermonde Island had a strong kinship network, as indicated by the distribution of their relatives on their islands, other islands, mainland, and Makassar, the capital city of South Sulawesi (Ferse et al. 2012). vital in a community.

The small-scale fisher-people in the Spermonde Islands can reap the benefit from their relation to the middlemen.

Natural capital As the primary source of livelihood, a fishing activity highly depends on the number of fish resources in the sea. There was 59.3 percent of people working as fisher-people. In addition, the other 32.9 percent of people working in fish-related activities, such as selling, collecting, and trading fish. The importance of the fish as the natural capital is also reflected in the 87.1 percent of households who did not have an alternative source of income.
Ornamental fisheries become the main livelihood of small-scale fisher-people in Barrang Lompo and Karanrang Islands, Spermonde

The ornamental fisheries also include ornamental coral reef fishing. The small-scale fisher-people in this area also caught food fish such as grouper, red grouper, and other fishes.

\section{Institutional Arrangement: Findings and Analysis}

\subsubsection{Awig-Awig and Pecelan Laut - Pemuteran, Bali Province}

Pemuteran Beach, Buleleng Regency, is located in the northern part of Bali Island. In Pemuteran, active community-based management has grown after the destructive fishing and cyanide poisoning practice in the 1950-1990 (Dunning, 2015). The community in this area used to comprise small-scale fisher-people in the same period of time. However, the destructive fishing 
practice has made them lose the productive and healthy coral reef in their region. During this period, Pemuteran was one of the most impoverished areas in Bali Province, where they still depend on their livelihood as fisher-people.

However, this type of self-governance community-based management has been practiced for a long time as the customs law for the local people in Bali and Lombok Island called awig-awig (Wanucha, 20I4). The awig-awig rules how to solve the ownership conflict among the villages about tour boat or fishing privilege. The awig-awig also determines the type of fishing gears that are not allowed to be used, such as Muro-ami and bombing (Satria, Matsuda, \& Sano, 2006).

Destructive fishing practice and cyanide poisoning had been prohibited under the Indonesian Fisheries Law Number 9 in I985 because of the harm from its practice to the coral reef. This condition happened at the same time when the tourism sector has risen in the Pemuteran in late 1980 to early I990. Since then, the tourism sector became the main livelihood of the Pemuteran villagers. However, they still depend highly on the coral reef as their livelihood because the tourists come to the area mainly for enjoying the beauty of the surrounding coral reef.

The importance of coral reef had made them construct the community-based management to conserve the coral reef. The pecelan laut is the group of sea police who has the responsibility to patrol the sea every Saturday and Sunday as part of their religious belief. They play the role of monitoring the commons from the destructive fishing practice. The pecelan laut had been claimed as the autonomous leaders in the coral reef management because The pecelan laut has more authority to govern the coral reef more than the local government official.

The pecelan laut arguably had also been considered as the most critical stakeholder in the community-based management of coral reef in Pemuteran, although Dunning (2015) believed that the pecelan laut is not a type of common-pool resources' governance but more like a social, cultural, and religious phenomenon. After the destructive fishing practice banned by the Indonesian government, the community's conservation effort had effectively recovered the destructive coral reef. The healthy status of the coral reef was captured from the community's perception of the coral reef in the area. More than 90 percent of the community believed that the coral reef condition in Pemuteran was healthy.

From the finding in Pemuteran's case study, the community's interest to govern the coral reef is not as significant as the tourism elites' interest who wanted to make sure the sustainability of the coral reef to attract tourists significantly. Hence, their self-governance of the shared pool resources was still determined by the tourism elites. Although the role of the pecelan laut is vital to monitor the marine area from the destructive fishing practice, the awig-awig failed to govern the community common pool resources without the intervention from other stakeholders. This finding was similar to the awig-awig in the Gili Indah (Satria et al. 2006), which proved that some self-governed institutions would be taken control by the local leaders or elite power who have their own interests (Ostrom, I999).

There were also unclear boundaries in the awig-awig system in Pemuteran, that is different from the characteristic of long-enduring common pool resources institution (Ostrom, I990). However, as has been mentioned above, the ineffectiveness of the awig-awig and pecelan laut system is not influenced much to the coral reef conservation. As the status of coral reef is improved, small-scale fisher-people in Pemuteran obtains better natural capital. Moreover, the rise of the tourism sector in Pemuteran also has raised their financial 
capital as they can undertake the alternative livelihood.

\section{Sasi - Raja Ampat Islands, West Papua Province}

The fishery sector is the main livelihood for the community in Fafanlap, Misool Island (McLeod et al. 2009). The importance of marine livelihood in Raja Ampat has been identified by the establishment of sasi, "a set of traditional practices and laws (adat) that control the exploitation of natural resources throughout much of eastern Indonesia" (McLeod, Szuster, \& Salm, 2009: 662).

The sasi has been the effective rule to conserve marine area and specifically coral reef. As its long history to determine the marine tenure system in eastern Indonesia, sasi has some rules for the community members. For instance, the rules specify which marine species can be caught, the type of fishing equipment that allowed being used, and the period of fishing. Sasi will not prohibit the community from doing fishing in some period, except during the stormy season. However, sasi can restrict the catch for some marine resources, such as sea cucumber, hawksbill turtle, shellfish, shrimp, and shark for six months, usually from April to September, in order to ensure the stock regeneration of the marine resources. The law has been inherited from generation to generation by word of mouth.

Previously, sasi was maintained by the adat leaders, but currently, sasi was managed by the village leaders or religious leaders. Moreover, the importance of sasi in both Fafanlap and Tomolol village has decreased. The modern world has changed the traditional belief and law in Raja Ampat. For example, the role of government law to prohibit destructive fishing practice was as significant as sasi. The introduction of bombs and cyanide fishing practices has caused sasi to adjust its law by restricting the destructive fishing practice. Before the destructive changing gear existed, it was unnecessary to limit the fishing gear used by the fisher-people.

In addition to its effectiveness in preventing destructive fishing practice and overfishing, sasi has successfully increased the number of sea cucumber, trochus, and lobster stocks in the sea (Boli, Yulianda, Damar, Soedharma, \& Kinseng, 20I4). Therefore, the sasi has created access for the small-scale fisher-people to the improved natural capital. Furthermore, the increase of fish production for the small-scale fisher-people will add their accumulation of financial capital. However, like the previous case study in Pemuteran, the implementation of sasi in Raja Ampat Islands is also constrained by the involvement of a private company to determine their interest in the conservation effort.

\section{CONCLUSION}

Theoretically, the environment and poverty are related. There were some theories tried to explain the nexus between environmental degradation and poverty (Reardon \& Vosti, I995; Angelsen, I997; Gould, 2009; Khan \& Khan, 2009), although the empirical evidence concluded that poor people are not the main cause of environmental degradation (Duraiappah, I998; Ravnborg, 2003; Khan \& Khan, 20II). Particularly in rural areas, the environmental degradation and poverty nexus relates to the poor people's livelihood since poor people in rural area usually utilize the natural resources as their main livelihood (World Bank, 2002; Millennium Ecosystem Assessment, 2005; WRI, 2005).

This study has attempted to understand the environmental degradation and poverty nexus in Indonesia by focusing on the coral reef destruction and small-scale fisher-people. The sustainable livelihood framework is used as the approach to the study, which can explain the small-scale fisher people's vulnerability and capacity to destruct.

As a result, in Jakarta Bay and Spermonde Islands, small-scale fisher-people have limited 
assets to overcome the coral reef destruction. To cope with the problem, they undertake destructive fishing practice that destroys the coral reef. Therefore, small-scale fisher-people have cumulative vulnerability because their strategy to overcome from the coral reef destruction has led them to become more vulnerable.

Moreover, self-governance common pool resources, such as awig-awig and pecelan laut in Pemuteran and sasi in Raja Ampat Islands, have positively affected coral reef sustainability. As the healthy coral reef can generate natural capital for the small-scale fisher-people, this type of common-pool resources governance can support the small-scale fisher-people to accumulate their assets and sustain their livelihood. The substantial social capital of the small-scale fisher-people can help the small-scale fisher-people to establish the self-governance common pool resources as the livelihood strategies, which will be explained in the below subsection.

However, this study also has some limitations. First, this study does not consider the contribution of other stakeholders than small-scale fisher-people to coral reef destruction. Second, the recommended livelihood strategy is limited to natural-based activities. However, non-natural-based activities such as the establishment of a credit market or training for small-scale fisher-people are not explained further in this study and suggested to be conducted for future study.

To conclude, some livelihood strategies are relevant to increase the small-scale fisher-people income and sustain the marine ecosystem according to the analysis. The fishing activity as the natural resource-based activities remains the primary source of livelihood for poor people in the coastal areas due to the ease of access to the marine area as the natural capital. However, the use of environmentally-friendly fishing practices should be emphasized in order to achieve marine sustainability.

The role of local wisdom such as awig-awig and pecelan laut in Pemutaran (Dunning, 2015) and sasi in Raja Ampat Islands (McLeod et al., 2009) is essential to govern the common pool resources. Those types of self-governance common pool resources support the prohibition of unsustainable fishing practices such as bombing and muro-ami. The conservation effort is essential to the small-scale fisher people's livelihood that affected the coral reef destruction.

Moreover, small-scale fisher-people must undertake livelihood diversification such as tourism in the Pemuteran (Baum et al., 2016) and pearl farming in the Tomolol, Raja Ampat Islands (McLeod et al., 2009). Livelihood diversification is essential to cope with environmental degradation. The livelihood diversification strategies are also involved the household members. For example, as the men go fishing, the women in the family can farm pearls (Cinner, 20I4).

\section{REFERENCES}

Allison, E. H. \& Ellis, F. (200I). 'The livelihoods approach and management of small-scale fisheries'. Marine Policy, 25, 377-388.

Angelsen, A. (I995). 'Introduction: The poverty of the environment and the environment of poverty'. In A. Angelsen \& M. Vainio (eds), Poverty and the Environment (pp. I-I8). Sabah: CROP/ADIPA/UNCTAD.

Angelsen, A. (I997). 'The poverty - environment thesis: Was Brundtland wrong?'. Forum for Development Studies, 24(I), I35-I54.

Baum, G., Kusumanti, I., Breckwoldt, A., Ferse, S. C. A, Glaser, M., Dwiyitno, Adrianto, L., van der Wulp, \& S., Kunzmann, A. (2016). 'Under Pressure: Investigating marine resourcebased livelihoods in Jakarta Bay and the Thousand Islands'. Marine Pollution Bulletin, IIO(2), 778-789

Baumann, P. (2002). Improving access to natural resources for the rural poor: A critical analysis of central concepts and emerging trends from a sustainable livelihoods perspective. Rome: Food and Agriculture Organisation.

Bebbington, A. (I999). 'Capital and Capabilities: A framework for analyzing peasant viability, rural livelihoods and poverty'. World Development 27(I2), 202I-2044.

Bene, C. (2003). 'When fishery rhymes with poverty: A first step beyond the old paradigm on poverty in small-scale fisheries'. World Development, 3I(6), 949-975. 
Boli, P., Yulianda, F., Damar, A., Soedharma, D. \& Kinseng, R. (2014). 'Benefits of sasi for conservation of marine resources in Raja Ampat, Papua'. Jurnal Manajemen Hutan Tropika (Journal of Tropical Forest Management), 20(2), I3I-I39.

BPS. (2015). Analysis of Fishing Household in Indonesia (Analisis Rumah Tangga Usaha Perikanan Di Indonesia). Jakarta: Statistics Indonesia.

BPS. (2016). The Overview of Poverty in Indonesia on March 20I6. Jakarta: Statistics Indonesia.

Burke, L., Selig, E. \& Spalding, M. (2002). Reefs at Risk in Southeast Asia. Washington: World Resource Institute

Cesar, H., Burke, L., \& Pet-Soede, L. (2003). The Economics of Worldwide Coral Reef Degradation. Arnhem: Cesar Environmental Economics Consulting.

Chambers, R. (I988). 'Sustainable livelihoods, environment and development: Putting poor rural people first'. Institute Development Studies DP 240.

Chambers, R. \& Conway, G. R. (I99I). 'Sustainable rural livelihoods: practical concepts for the $2 \mathrm{I}^{\text {st }}$ century'. IDS Discussion Paper 296.

Cinner, J. (2014). 'Coral reef livelihoods'. Current Opinion in Environmental Sustainability, ,: 65-7I.

DFID. (I999). Sustainable Livelihoods Guidance Sheets. London: Department for International Development

Dunning, K. H. (20I5). 'Ecosystem services and community-based coral reef management institutions in post blast-fishing Indonesia'. Ecosystem Services, I6, 319-332.

Duraiappah, A. (I998). 'Poverty and environmental degradation: A review and analysis of the nexus'. World Development, 26(I2), 2169-2I79.

Ellis, F. (200o). Rural Livelihoods and Diversity in Developing Countries. Oxford: Oxford University Press.

FAO. (2005). Small-Scale Fisheries: Assessing Their Contribution to Rural Livelihoods in Developing Countries. Rome: Food and Agriculture Organisation.

Ferse, S. C. A., Knittweis, L., Krause, G., Maddusila, A., \& Glaser, M. (2012). 'Livelihoods of ornamental coral fishermen in South Sulawesi/ Indonesia: Implications for management'. Coastal Management, 40(5), 525-555.

Freed, S. \& Granek, F. (20I4). 'Effects of human activities on the world's most vulnerable coral reefs: Comoros case study'. Coastal Management, $42(2), 280-296$.
Gould, W. T. S. (2009). Population and Development. Oxon: Routledge.

Hardin, G. (I968). 'The tragedy of the commons'. Science, I62(3859), I243-I248.

Jehan, S. \& Umana, A. (2003). 'The Environmentpoverty Nexus'. Development Policy Journal March 2003: 53-70.

Khan, S. R. \& Khan, S. R. (2009). 'Assessing povertydeforestation links: Evidence from Swat, Pakistan'. Ecological Economics, 68(10), 2607-26i8.

Khan, S. R. \& Khan, S. R. (20II). 'Fishery degradation in Pakistan: a poverty-environment nexus?. Canadian Journal of Development Studies, I(32), 32-47.

Lefever, S., Dal. M., \& Matthiasdottir, A. (2007). 'Online data collection in academic research: advantages and limitations'. British Journal of Educational Technology, 38(4), 574-582.

McGregor, D. F. M., Barker, D., \& Evans, S. L. (I998). Resource Sustainability and Caribbean Development. Kingston: The Press University of the West Indies.

McLeod, E., Szuster, B., \& Salm, R. (2009). 'Sasi and marine conservation in Raja Ampat, Indonesia'. Coastal Management, 37, 656-676.

Millennium Ecosystem Assessment. (2005). Ecosystems and Human Well-being: Synthesis. Washington DC: Island Press.

Nadkarni, M. V. (200o). 'Poverty, environment, development: A many-patterned nexus'. Economic and Political Weekly, 35(I4), II84-II90.

Ostrom, E. (I990). Governing the Commons. New York: Cambridge University Press.

Ostrom, E. (I999). 'Coping with tragedies of the commons'. Annual Review Political Science, 2, 493-535.

Ostrom, E. (20I0). 'The challenge of self-governance in complex contemporary environments'. The Journal of Speculative Philosophy, 24(4), 316-332.

Parekh, G., Killoran, I., \& Crawford, C. (20II). 'The Toronto connection: Poverty, perceived ability, and access to education equity'. Canadian Journal of Education, 34(3), 249-279.

Ravnborg, H. M. (2003). 'Poverty and environmental degradation in the Nicaraguan hillsides'. World Development, 3I(II), I933-I946.

Reardon, T. \& Vosti, S. A. (I995). 'Links between rural poverty and the environment in developing countries: Asset categories and investment poverty', World Development, 23(9), I495-I506. 
Satria, A., Matsuda, Y., \& Sano, M. (2006). 'Questioning Community-based Coral Reef Management Systems: Case Study of Awig-Awig in Gili Indah, Indonesia'. Environment, Development and Sustainability, 8(I), 99-II8.

Scoones, l. (I998). 'Sustainable rural livelihoods: A framework for analysis'. IDS Working Paper, (72).

UNDP. (I998). Human Development Report. New York: United Nations Development Programme.

UNEP. (200o). Global Environment Outlook. Nairobi: United Nations Environment Programme.

Wanucha, G. (20I4, July I). Going Local in the Coral Triangle. Retrieved from Oceans at MIT Website: http://oceans.mit.edu/news/ featured-stories/coral-triangle
World Bank. (2002). The Environment and the Millennium Development Goals. Washington: World Bank.

World Bank. (2007). Poverty and the Environment: Understanding Linkages at the Household Level. Washington: World Bank.

World Commission on Environment and Development. (I987). Our Common Future. Oxford: Oxford University Press.

WRI (20I4, May 30) Atlas of Forest and Landscape Restoration Opportunities. Retrieved June 7, 2016, from World Resources Institute: http:// www.wri.org/resources/maps/atlas-forestand-landscape-restoration-opportunities 